\title{
The Role of University in the Education of Professional Accountants: Degree of IES 2 Application
}

\author{
Monica Veneziani, Claudio Teodori, Giulia Bendotti \\ University of Brescia, Brescia, Italy
}

\begin{abstract}
In the period following the beginning of the global economic crisis, the quality of the education provided to support the accounting profession was debated. Simultaneously, Education for Sustainable Development (ESD) is becoming increasingly important. The change in the accounting profession and in accounting education offers an opportunity to formulate initial observations on the Italian university world in terms of the preparation of future professional accountants. This study uses the International Education Standards (IESs) published by the International Accounting Education Standards Board (IAESB), in particular the IES 2 (content of professional accounting education programs). The aim of the paper, which is of an empirical nature, is to understand the role of universities in Italy in the preparation of accountants in the light of the IES 2 provisions. The study and its policy implications may contribute to the debate on accounting education at national and international levels, also in the light of ESD.
\end{abstract}

Keywords: university education programs, professional accountants, IES 2, Italy, ESD

\section{Background}

In the period immediately following the beginning of the global financial crisis, especially at international level, the quality of the education provided to support the accounting profession was debated, as it had been in previous years following the Enron and WorldCom scandals (Sikka, Haslam, Kyriacou, \& Agrizzi, 2007; Humphrey, Loft, \& Woods, 2009; Humphrey, Kausar, Loft, \& Woods, 2011). Simultaneously, Education for Sustainable Development (ESD) is becoming increasingly important. The change in the accounting profession and in accounting education (Graham \& Neu, 2003; Howieson, 2003; Broadbent \& Laughlin, 2005), therefore, offers an opportunity to formulate initial observations on the Italian university world in terms of the preparation of future professional accountants (Veneziani, 2012). This study uses the International Education Standards (IESs), in particular the IES 2 (content of professional accounting education programs), published by the International Accounting Education Standards Board (IAESB), established by the International Federation of Accountants (IFAC) in 2003.

The IFAC is the global organisation for the accountancy profession dedicated to serving the public interest by strengthening the profession and contributing to the development of strong international economies. IFAC is comprised of 175 members and associates in 130 countries and jurisdictions, representing approximately 3 million accountants in public practice, education, government service, industry, and commerce (IFAC, 2016). Few other professional organisations enjoy the broad international support that characterises the IFAC (Loft, Humphrey, \& Turley, 2006; Black, 2008; Crawford, Helliar, Monk, \& Veneziani, 2014).

Monica Veneziani, professor in Accounting, Department of Economics and Management, University of Brescia. Email: monica.veneziani@unibs.it.

Claudio Teodori, professor in Accounting, Department of Economics and Management, University of Brescia.

Giulia Bendotti, Ph.D. in Accounting, Department of Economics and Management, University of Brescia. 
IFAC's mission is:

To serve the public interest by: contributing to the development of high-quality standards and guidance; facilitating the adoption and implementation of high-quality standards and guidance; contributing to the development of strong professional accountancy organizations and accounting firms and to high-quality practices by professional accountants, and promoting the value of professional accountants worldwide; and speaking out on public interest issues. (IFAC, 2010a, p. 1)

To pursue its mission, in 2003 the IFAC Board established the IAESB as an independent standard-setting body for formation and publication of the IES for professional accountants. In particular, the mission of the IAESB is to pursue the public interest by strengthening the accounting profession worldwide via the development and improvement of accounting education as a whole (Needles, 2008). The activity of this organisation is based on the assumption that improvement in the educational aspect in turn improves the ability of the profession to meet the information needs of the decision-makers. Furthermore, promotion of the IES can help to:

(1) Reduce the differences in the various countries in the requirements for becoming a professional accountant (Cooper \& Robson, 2006; Suddaby, Gendron, \& Lam, 2009);

(2) Incentivise the international mobility of professional accountants;

(3) Provide common benchmarks at world level for comparison in the ambit of accounting education and professional practice (Hall \& Sen, 2004; IFAC, 2010b).

By ensuring that each member meets the requirements, IFAC sets itself the objective of contributing to international convergence in the ambit of accounting education and accounting practice (Lehman, 2005; 2009). In detail, each IFAC member, for Italy the Consiglio Nazionale dei Dottori Commercialisti e degli Esperti Contabili (CNDCEC, National Council of Professional Accountants and Accounting Experts), has to periodically fill in specific documents (Crawford, Helliar, Monk, Mina, Teodori, Veneziani, Wanyama, \& Falgi, 2010), demonstrating that it meets the requirements imposed by the IFAC on its members, including application and promotion of the IESs for professional accountants and other IAESB guidance (Needles, Kantor, \& Shoenthal, 1992).

The IFAC (and therefore its members), via its mission, actively participates in the ESD world debate that goes back to the beginning of the 2000s (Cooper, Neu, \& Lehman, 2003; Everett, 2003). ESD:

(1) Is based on the principles and values that underlie sustainable development;

(2) Deals with the well-being of all four dimensions of sustainability: environment, society, culture, and economy;

(3) Uses a variety of pedagogical techniques that promote participatory learning and higher-order thinking skills;

(4) Promotes lifelong learning;

(5) Is locally relevant and culturally appropriate;

(6) Is based on local needs, perceptions, and conditions, but acknowledges that fulfilling local needs often has international effects and consequences;

(7) Engages formal, non-formal, and informal education;

(8) Accommodates the evolving nature of the concept of sustainability;

(9) Addresses content, taking into account context, global issues and local priorities;

(10) Builds civil capacity for community-based decision-making, social tolerance, environmental stewardship, an adaptable workforce, and a good quality of life; 
(11) Is interdisciplinary. No single discipline can claim ESD for itself; all disciplines can contribute to ESD. Certainly, accounting is a discipline that can play a key role for the $\mathrm{ESD}^{1}$.

What appears evident from the analysis of some accounting education studies is that the evolution of education towards sustainable development has been very slow. Sterling (2001) attempted to deal with this problem in his Schumacher Briefing in 2001: in the study, he criticises the current educational model and outlines an alternative model coherent with a perspective that stimulates reflection on the problem of a sustainable future. In its personal definition, the ESD consists in "developing awareness and promotion of a change in terms of attitudes and values, which translates into actual involvement in sustainable development".

Sahlberg and Oldroyd (2010) observed that a fundamental point of education reform, which focuses on economic competitiveness and environmental sustainability, should be to provide students with the necessary tools to adapt to an unpredictable and changing business and commercial world (Helliar, Michaelson, Power, \& Sinclair, 2000; Beattie, Fearnley, \& Hines, 2012).

Hargreaves (2003) in this regard maintained that individuals must be able to work with knowledge, play with new ideas, collaborate with other people and adapt to situations that can suddenly change.

National economic competitiveness is connected with intellectual and creative capital and is therefore determined by knowledge, creativity, and innovation. Analogously, Murgatroyd (2010) maintained that sustainable development requires an understanding of the complexity of the global ecosystem and the application of creative problem-solving, in order to find solutions to very difficult problems, such as reconciling economic activity with minimum environmental impact.

Also, the IFAC suggests that the approach to teaching, with reference to the IES standards, should be centred on the learner (IFAC, 2010b) and that it should be participatory (IES 4, Par. 20), encouraging students to actively engage in the learning process (Boyce, Williams, Kelly, \& Yee, 2001; Adler, Whiting, \& Wynn-Williams, 2004; Daff, 2012).

The education of professional accountants in Italy starts at university and is completed after the degree via professional training experience and the state qualifying examination. It is, therefore, important to explore to what extent the IESs are followed at university, where much of the professional accountancy preparation work is carried out.

Adoption of the IES at university level and in accounting practice is a fundamental step for the education of professional accountants, offering them the opportunity to play an active role in the international debate on improvement of the profession in the light of the new requirements of the ESD. Ignoring these international standards (IES) would mean producing professional accountants without an international vision of the profession and with competences that can be used mainly in the local area.

This is the background to our empirical paper, the aim of which is to understand the role of the university in Italy in the preparation of accountants in the light of the provisions of the IES 2 in particular. More specifically, the research questions are the following:

(1) What are the characteristics of the Italian university programs geared to the preparation of accountants?

(2) To what extent do the study programs offered reflect the provisions of the IES $2^{2}$ ?

\footnotetext{
1 Retrieved from www.unesco.org. Themes: Education - Education for Sustainable Development.

2 IES 2: Version available in 2012/2013.
} 
This research focuses on a theme that has not been widely discussed in Italy. Therefore, this study and its policy implications may contribute to the debate on accounting education at national and international levels, also in the light of ESD.

The paper is organised as follows: section two is dedicated to presentation of the structure of the Italian university degrees and to the path leading to professional accountancy; section three highlights the method adopted; in section four, the results are discussed and the last section presents discussion, conclusions, and future developments.

\section{Professional Accounting Education in Italy}

The Italian university education system is organised in several levels. The three main levels are: undergraduate degree (first level), master degree (second level), and doctoral degree (Ph.D.) or specialisation schools (especially in medicine). Alongside these main levels, there are also other university qualifications which could be defined as specialisation courses: first level qualifications which can be acquired after the undergraduate degree and second level qualifications, acquired after the master degree. With the exception of the doctorates, which are organised very freely, the other education programs have a duration expressed in educational credits and years as summarised in Table 1.

Table 1

The Italian University Education System

\begin{tabular}{lll}
\hline Degree/Ph.D./specialisation & Duration in years & Educational credits \\
\hline Undergraduate degree & 3 & 180 \\
Master degree & 2 & 120 \\
Unique degree & $5 / 6$ & $300 / 360$ \\
Doctorate (Ph.D.) & $3 / 4$ & $\mathrm{nc}$ \\
Specialisation courses (first level) & 1 & 60 \\
Specialisation courses (second level) & 1 & 60 \\
\hline
\end{tabular}

Only the undergraduate and master degrees are relevant here.

Within the education programs, each university has a relative autonomy in the sense that it can decide how many (subject to certain size limits) and what education programs to offer but it is not free to define all the contents. In Italy, every degree has to be constructed with reference to a specific class identified by a ministerial code: there are 187, 43 of which are undergraduate courses, 87 masters, and seven unique degrees. Of these, only four (L18, L33, L77, and L56), albeit different degrees, directly concern the accounting profession.

Another fundamental premise concerns the "identification" parameters of the university professors: each one belongs to only one scientific-disciplinary sector according to the contents of his/her research activity. The sector (there are approximately 350) is important for the purposes of competitive examinations and the planning of degree programs.

Returning to the main aspect, for each degree class the Ministry defines the minimum number of credits for each type of educational activity (lessons, stage, seminars...) and the scientific sectors that make up each activity. The university's autonomy is therefore limited: this slows down the phase of adaptation to changing needs and also results in lack of uniformity between universities. Undergraduate or postgraduate courses with the same names can have very different contents; programs with very different characteristics, purposes, contents, and structures can coexist in the same degree class. 
In Italy, there is only one professional accounting body, which is a member of IFAC, the CNDCEC which has a number of area associations denominated Ordine dei Dottori Commercialisti e degli Esperti Contabili (ODCEC) that generally coincide with the Italian provinces. Each area association has considerable autonomy and the only element that all the area associations have in common is Italian law that regulates how to become a professional accountant.

The accounting profession is completely regulated by the law (Legislative Decree of 28 June 2005, No. 139). The Legislator therefore decides: professional qualification procedures (class of degree, training period, state examination subjects, organisation of the state examination...), the activity of the profession, i.e., what professional accountants can and cannot do.

Under the 2005 Legislative Decree, to practise as a professional accountant, it is obligatory to be enrolled in the CNDCEC Register which is divided into two sections: Section A for professional accountants and Section B for accounting experts. The professions can only be registered in only one section of the Register for the local area where they practise; there are no divisions between whether a member is in practice or works in business. For enrolment of accountants in Sections A and B of the Register and to exercise the profession of accountant, applicants must have the following educational qualifications: (1) a master degree (Section A), undergraduate degree (Section B) in one of the following areas: economics, management, accounting, and finance; (2) completed an eighteen-month training period specific for professional accountants (Section A) and accounting experts (Section B); and (3) passed the state qualifying examination after the specific eighteen-month accountancy training period. Separate state examinations are held for access to either Section A or Section B of the Register. In short, the professional accountant has a wider theoretical and practical knowledge of accounting in the broad sense, and thus can work more extensively and perform more functions than an accounting expert.

On October 13, 2010 (in accordance with the Legislative Decree No. 139), the Framework Agreement was signed between the Ministry of Education, University and Research and CNDCEC, significantly intensifying the collaboration between university and profession. It should be noted that the effects of these agreements began to manifest themselves as from 2011. More specifically, the Framework Agreement, on the basis of certain competences acquired in the accredited courses or accredited degrees, offers facilitations for access to the accounting profession. In particular, students are exempted from the first test (out of three) if they have studied at university the topics of accounting, auditing, business administration, and law. In order to implement in practice the provisions of the Framework Agreement, the area associations (ODCEC) must have specific agreements with each university in which these accredited courses are jointly developed; this new feature represents a significant step forward in connecting the accounting profession and universities in Italy. The integration between the universities and the area associations should allow more effective delineation of the overall training path followed by the future professional, coordinating the content of the degree programs, the content of the professional courses for preparation of the state examination organised by the area association (ODCEC) and the characteristics of the professional training.

\section{Method}

To achieve the objective of the paper, the research work was carried out in the following phases:

(1) Choice of the education programs to be analysed on the basis of degree class concerns accounting profession established by Italian law; 
(2) Study of the IES 2 standard to identify the macro-subjects of the professional accounting education programs used subsequently in the model for analysis and definition of the aggregation criteria of the macro-subjects into knowledge areas more consistent with Italian law.

The first methodological aspect relates to identification of the education programs designed to prepare students for the accounting profession. In this regard, under the law that defines the qualifications required for accountants to be enrolled in the Professional Register, the departments of economics study programs for both undergraduate degrees and master degrees in the academic year 2012/2013 are considered. In particular, the analysis considers all the types of undergraduate degrees in class L18 (management and business administration) and L33 (economics) and the master degrees in class L77 (management and business administration) and L56 (economics). The study involves all the study programs within the degree class in addition to the various curricula into which the programs are organised.

The programs analysed were identified by consulting the Ministry of Education, University and Research web portal which describes the Italian education programs offered. Overall, the research involved the analysis of 516 programs: 222 belonging to the undergraduate degrees (69 of which are in class L33 and 153 in class L18) and 294 belonging to the master degrees (86 of which are in class L56 and 208 in class L77). The research considers firstly the education programs offered by the undergraduate degrees separately from the master degrees. Secondly, the results presented provide a joint study of the two programs via data aggregation, by virtue of the fact that enrolment in the CNDCEC Register (Section A) requires the possession of a master degree (five-year degree).

The second methodological aspect defines the research analysis theme: the subjects and the respective corresponding educational credits for each study program are identified and classified. The classification criterion places the individual subject within the analysis model constructed on the basis of the macro-subjects identified by the IES 2: financial accounting and reporting, management accounting and control, taxation, business and commercial law, audit and assurance, finance and financial management, financial markets, economics, business environment, international business and globalisation, corporate governance, business ethics, organisational behaviour, management and strategic decision-making, marketing, general knowledge of IT, IT control knowledge, IT control competences, IT user competences, designer of information systems, professional values and ethics, and quantitative methods.

The macro-subjects defined by the IES 2 were aggregated into six knowledge areas in order to interpret the results more easily with the classification most coherent with the Italian university organisation. The knowledge areas are as follows: business administration, economics, business and law, ethics, mathematics, and IT. The business administration area comprises: financial accounting and reporting, management accounting and control, audit and assurance, finance and financial management, financial markets, corporate governance, organisational behaviour, management and strategic decision-making, and marketing; the economic area brings together: taxation, economics, business environment, international business and globalisation; the business and law area comprises business and commercial law; the ethics area combines business ethics, professional values and ethics. Lastly, the IT area comprises the general knowledge of IT, IT control knowledge, IT control competences, IT user competences and designer of information systems; and the mathematics area comprises the topics placed in the quantitative methods. 
An adaptation had to be included in the analysis model described above to take account of the educational credits that cannot be placed in the IES 2 model because they relate to activities not included in the macro-subjects considered in the international standard or which cannot be uniquely classified in the model. These credits, which in the analysis model come under the category "other", refer to the following types of activity: stage experience, seminars, linguistic skills, final thesis (educational activities and contents not comprised in the model), educational activities chosen by the student and optional credits (which cannot be uniquely classified). The national university system, in accordance with the principle of educational autonomy, offers students the possibility of personalising their study programs via a certain number of credits chosen by the student and a certain number of optional credits. The optional credits are defined by the individual student within his/her study program with reference to a group of examinations established by the university while those selected by the student can be freely chosen from those offered by the all education program. The definition of optional examinations and those chosen by the student is therefore correlated with decisions of a subjective nature in composition of the study program and for this reason cannot be attributed to one single knowledge area.

\section{Results}

One characteristic common to all the degree programs leading to professional training is the presence of educational credits that cannot be placed in the IES. Table 2 illustrates both in absolute and percentage terms (mean values), for each degree class, the mandatory credits attributed to the subjects classified in the IES model and the credits attributed to the category "other" as described above (see Table 2).

Table 2

Distribution of the Educational Credits

\begin{tabular}{|c|c|c|c|c|c|c|c|c|c|c|c|c|}
\hline & \multicolumn{4}{|c|}{ Undergraduate degrees } & \multicolumn{4}{|c|}{ Master degrees } & \multicolumn{4}{|c|}{ Five-year degrees } \\
\hline & \multicolumn{2}{|c|}{ L18 } & \multicolumn{2}{|c|}{ L33 } & \multicolumn{2}{|c|}{ L77 } & \multicolumn{2}{|c|}{ L56 } & \multicolumn{2}{|c|}{ L18+L77 } & \multicolumn{2}{|c|}{ L33+L56 } \\
\hline & $\begin{array}{l}\text { Mean } \\
\text { MEC }\end{array}$ & $\begin{array}{l}\% \\
\text { MEC }\end{array}$ & $\begin{array}{l}\text { Mean } \\
\text { MEC }\end{array}$ & $\begin{array}{l}\% \\
\text { MEC }\end{array}$ & $\begin{array}{l}\text { Mean } \\
\text { MEC }\end{array}$ & $\begin{array}{l}\% \\
\text { MEC }\end{array}$ & $\begin{array}{l}\text { Mean } \\
\text { MEC }\end{array}$ & $\begin{array}{l}\% \\
\text { MEC }\end{array}$ & $\begin{array}{l}\text { Mean } \\
\text { MEC }\end{array}$ & $\begin{array}{l}\% \\
\text { MEC }\end{array}$ & $\begin{array}{l}\text { Mean } \\
\text { MEC }\end{array}$ & $\begin{array}{l}\% \\
\text { MEC }\end{array}$ \\
\hline MEC - IES 2 model & 137.28 & 76.27 & 141.69 & 78.71 & 80.63 & 67.19 & 79.72 & 66.44 & 217.91 & 72.64 & 221.41 & 73.80 \\
\hline $\begin{array}{l}\text { Other (optional } \\
\text { subjects, stage, } \\
\text { linguistic activities, } \\
\text { seminars) }\end{array}$ & 42.72 & 23.73 & 38.31 & 21.29 & 39.37 & 32.81 & 40.28 & 33.56 & 82.09 & 27.36 & 78.59 & 26.20 \\
\hline Total value & 180.00 & 100.00 & 180.00 & 100.00 & 120.00 & 100.00 & 120.00 & 100.00 & 300.00 & 100.00 & 300.00 & 100.00 \\
\hline
\end{tabular}

Note. MEC = Mandatory education credits.

From Table 2, it emerges that for the undergraduate degrees, the mandatory education credits (MEC) classifiable in the IES 2 model are higher than those of the master degrees. This gives students greater scope for personalising the study program of the two-year master degree according to personal professional objectives. No particular differences emerge in percentage terms between the programs at the same level and in different degree classes. In the five-year program, the credits classified in the IES 2 model account for $72.64 \%$ of the overall credits for the degree in management and business administration (L18+L77) and $73.80 \%$ for the economics program.

The results below are relative to analysis of the mandatory credits that fall within the content categories (macro-subjects) established in the IES 2 model. The picture that emerges is therefore complete and exhaustive as regards the mandatory examinations defined by the single study programs. For greater clarity, it is 
highlighted that the analysis considers with reference to the number of mandatory subjects and educational credits (see Appendices A-F): the overall values in absolute terms; the mean overall values in absolute terms and the respective mean percentage; the minimum and the maximum percentage values. More specifically, the results refer firstly to the mandatory credits established in the undergraduate programs (L18 and L33) offering a comparison between the two classes. This is followed by analysis of the mandatory credits established in the two-year master program (L77 and L56): here the aim is to highlight the differences in terms of representation of knowledge areas compared to the respective undergraduate programs. Lastly, a comment is made on the aggregate results of the entire five-year program (L18+L77 and L33+L56).

\section{Undergraduate Degrees}

The undergraduate program L18 in management and business administration (see Appendix A, Panel 1, Table A1) shows a percentage representation for all the macro-subjects defined by the IES 2. However, for six macro-subjects of the model (taxation, audit and assurance, international business and globalisation, corporate governance, business ethics, professional values and ethics), the percentage representation is below one percentage point. General knowledge of IT covers $4.36 \%$ of the subjects, equal to a mean of $2.25 \%$ of the MEC, while the other subjects of the IT category have residual values (below 1\%).

The analysis reports a mean number of mandatory subjects equal to 17.56 corresponding to a mean value of MEC classified in the model equal to 137.28 out of the total of 180 (see Table 2).

This study program is dominated, with $19.73 \%$ of the MEC, by business and commercial law (maximum values of $33.78 \%$ and minimum values of $9.84 \%$ of the credits), followed in order by quantitative methods (17.34\%), economics (17.18\%) (with values up to $29.41 \%)$, financial accounting and reporting (13.66\%), and management and strategic decision-making (8.41\%). The other macro-subjects have a percentage representation in terms of educational credits varying from $1 \%$ to $3 \%$. The following subjects present minimum values different from zero: quantitative methods (15.38\%), business and commercial law (9.84\%), economics (7.50\%), and financial accounting and reporting (6.12\%).

If we consider the aggregation of the contents of the IES 2 into the six knowledge areas (see Appendix A, Panel 1, Table A2) as previously identified in the methodology, it can be observed that in this undergraduate program, the majority of the credits relate to the business administration area (39.33\%), corresponding to 38.59\% of the mandatory subjects, followed in order by economics (20.30\%), business and law (19.73\%), and lastly mathematics (17.34\%). The percentage representation of the credits relating to the IT area is residual (2.68\%) and likewise ethics (0.62\%).

The undergraduate program L33 in economics (see Appendix B, Panel 2, Table B1), as previously, covers all the macro-subjects of the IES 2 except for corporate governance and IT control competences, which have a zero percentage. Seven macro-subjects of the model have representation below one percentage point, some of which are common also to the other undergraduate programs: management accounting and control, audit and assurance, international business and globalisation, organisational behaviour, marketing, business ethics, professional values and ethics. General knowledge of IT covers $4.42 \%$ of the subjects equal to a mean of $2.10 \%$ of the MEC, while residual values are obtained (below 1\%) for the other contents of the IT category.

The analysis reports a mean number of 17.69 mandatory subjects corresponding to 141.69 credits out of a total of 180 (see Table 2). 
$28.59 \%$ of the educational credits concern subjects classified in "economics” which unlike the undergraduate program L18 come out top with a maximum value of 51.11\%, followed by those relative to quantitative methods (23.00\%), business and commercial law (17.51\%), and financial accounting and reporting (10.57\%). The other macro-subjects vary from a credit percentage of between 0 and 3 percentage points. Also for this undergraduate program, the following subjects have minimum values different from zero: quantitative methods (13.33\%), business and commercial law (11.11\%), economics (8.70\%), and financial accounting and reporting (5.37\%).

Considering the aggregation of the subjects in the six knowledge areas (see Appendix B, Panel 2, Table B2), a different representation order of educational credits is observed since the economics area (35.34\%) is dominant in percentage terms. This is followed by the business administration area which, although contains a higher number of macro-subjects identified by the IES 2 and summarised in the model, accounts for $21.26 \%$ of the credits. The mathematics area has a higher percentage equal to $23.00 \%$, while the business and law area has a lower representation equal to $17.51 \%$.

For the two classes of undergraduate degree, a difference in representation order of the topics indicated in IES 2 is observed, which is also reflected in the aggregate knowledge areas. This is coherent with the different bias characterising each degree class.

\section{Master Degrees}

The master program L77 in management and business administration (see Appendix C, Panel 3, Table C1) shows a percentage representation of all the macro-subjects defined by the IES 2 with the exception of IT control competences. For taxation and audit and assurance, a representation of one percentage point emerges. It is important to note, however, that this program shows an increase in representation of macro-subjects which are poorly represented in the respective undergraduate course L18 (international business and globalisation, corporate governance, and business ethics). IT, on the other hand, is neglected and is the only one with modest percentages also in the master program.

The analysis reports a mean number of mandatory subjects of 11.08 corresponding to a mean value of MEC of 80.63 out of the total of 120 of the master program (see Table 2).

In the master program, the representation order changes with respect to the undergraduate program: business and commercial law confirms its dominant position with $14.82 \%$ of the educational credits with maximum values of $37.50 \%$, followed by management and strategic decision-making (14.35\%), financial accounting and reporting (11.87\%), economics (11.34\%), and quantitative methods (10.47\%). Finance and financial management also takes on greater importance with $6.20 \%$ and marketing with $6.33 \%$. The other macro-subjects confirm their residual role with a representation in terms of educational credits varying from $1 \%$ to $3 \%$. We also record the presence of maximum values that differ considerably from the mean values for all the topics of the model, whereas zero is the minimum recurrent value.

The aggregation of the contents of the IES 2 into the six knowledge areas (see Appendix C, Panel 3, Table C2) shows that the majority of the credits refer to the business administration area even more so than in the undergraduate program with $51.96 \%$ corresponding to over half of the mandatory subjects. This is followed in order of educational credits by economics (19.64\%), business and law (14.82\%), and lastly mathematics $(10.47 \%)$. As already highlighted, the percentage representation of the credits referring to the IT area is residual $(0.70 \%)$. For the ethics area $(2.41 \%)$, an increase of more than one percentage point is observed compared to the undergraduate degree L18. 
The master program L56 in economics (see Appendix D, Panel 4, Table D1) covers all the macro-subjects of the IES 2 except for the IT topics (control knowledge, control competences, user competences) which have a zero percentage. Three macro-subjects of the model have representation below one percentage point, common also to the undergraduate program L33: organisational behaviour, business ethics, professional values and ethics. Knowledge relative to audit and assurance is higher than one percentage point (1.26\%), while knowledge of corporate governance increases from $0.00 \%$ to $0.25 \%$ educational credits compared to L33. International business and globalisation records an increase of more than four percentage points compared to the undergraduate program. IT is characterised almost entirely in every subject by zero values. The absence of IT knowledge other than very general or basic knowledge is again evident, as highlighted for the other degree programs.

The analysis reports a mean number of 10.36 courses corresponding to 79.72 mandatory credits out of a total of 120 credits established by the specialist program (see Table 2).

$29.05 \%$ of the educational credits can be attributed to economics which, like the undergraduate program L33, comes out top with a maximum value of $63.33 \%$, followed by quantitative methods $(20.66 \%)$ and business and commercial law (14.25\%). The topics relating to financial accounting and reporting are considerably reduced (3.81\%) compared to the undergraduate program L33 whereas those referring to management and strategic decision-making (6.82\%) and business environment increase. The other macro-subjects vary, with a percentage of educational credits of between 0 and 3 percentage points. As in the master program L77, the presence of maximum values differing considerably from the mean values for all the topics of the model is identified; here again, zero is the minimum recurrent value.

Considering the aggregation of the subjects into the six knowledge areas (see Appendix D, Panel 4, Table D2), a similar representation order (compared to L33) is observed since the economics area $(40.70 \%)$ is confirmed to be dominant, followed by the business administration area, which represents $22.58 \%$ of the educational credits, the mathematics area with a higher percentage equal to $20.66 \%$, and lastly, business and law with a representation of $14.25 \%$.

For the two classes of master degree as for the undergraduate degrees, we observe a difference in representation order of the subjects indicated in the IES 2 which is also reflected in the knowledge areas.

\section{Five-Year Degrees}

The five-year degree in management and business administration (see Appendix E, Panel 5, Table E1) shows a percentage representation of all the macro-subjects defined by the IES 2 except for the topics relative to IT (for which only a minimum percentage of courses associated with general knowledge is recorded - 1\%).

The analysis reports a mean number of mandatory subjects equal to 28.64 corresponding to a mean value of MEC of 217.91 out of the total of 300 for the five-year degree (see Table 2).

In this study program, business and commercial law dominates with $17.55 \%$ of the MEC, followed by economics (14.59\%), quantitative methods (14.29\%), financial accounting and reporting (12.87\%), and management and strategic decision-making (11.04\%). The other macro-subjects have representation in terms of educational credits varying from $1 \%$ to $5 \%$.

If we consider aggregation of the contents of the IES 2 into the six knowledge areas (see Appendix E, Panel 5, Table E2), it can be observed that in this five-year degree, the majority of the credits refer to the business administration area (44.93\%) followed in order by economics (20.01\%), business and law (17.55\%), and mathematics $(14.29 \%)$. The percentage representation of the credits relating to IT $(1.81 \%)$ and ethics $(1.41 \%)$ is residual. 
The five-year degree in economics (see Appendix F, Panel 6, Table F1) similarly to previously shows a percentage representation of all the macro-subjects defined by the IES 2 except for the topics referring to IT (for which only a minimum percentage of courses associated with knowledge of a general nature is recorded $(1.34 \%))$.

The analysis reports a mean number of 28.05 mandatory subjects corresponding to 221.41 credits out of a total of 300 (see Table 2).

28.78\% of the educational credits can be attributed to economics, followed by quantitative methods (22.03\%), business and commercial law (16.16\%), and financial accounting and reporting (7.77\%). The other macro-subjects vary, with a percentage of educational credits between 1 and 5 percentage points.

Considering the aggregation of the macro-subjects into the six knowledge areas (see Appendix F, Panel 6, Table F2), we observe a different representation order of educational credits with respect to the other five-year degree since the economics area (37.56\%) is dominant in percentage terms. This is followed by the business administration area which, although contains a greater number of topics identified by the IES 2 and summarised in the model, is characterised by $21.81 \%$ of the educational credits. The business and law area (16.16\%) records a representation similar to that of the five-year degree in management and business administration. The mathematics area has a higher value in the program analysed (22.03\%).

For the two five-year degrees, we observe in short a difference in terms of order of representation of the macro-subjects indicated in the IES 2. From this, greater compliance of the management and business administration program (L18+L77) with the contents defined by the international standard emerges.

The five-year degrees tend to integrate topics in the master program that are not well represented in the undergraduate program.

The aggregation into knowledge areas is in line with the orientation of the studies identified by the different degree classes. The dominant areas are confirmed to be the same in the undergraduate and master program for both the degree classes.

The teaching of IT and ethics is limited to knowledge of a general nature achieved at the end of the undergraduate program. The master program does not perform any additional function.

Lastly, it is observed that the variance of the minimum and maximum values of the credits associated with each macro-subject of the IES 2 model with respect to the mean value is an indicator of the presence of highly diversified study programs. This characteristic is a direct consequence of the autonomy which the individual universities exercise in the organisation of their courses, especially in the master programs.

\section{Discussion and Conclusion}

The results of the analysis enabled us to draw up a first reference framework of the Italian situation, providing the basis for an in-depth national reflection and future international comparisons.

Going back to the initial research questions, it emerged that the education programs, especially at the first level (undergraduate degrees), are not directly functional to the accounting profession, generating a significant gap vis-à-vis the characteristics of the figure of the accountant: this is fairly inevitable, due to the more generalist nature of these programs and the need, evident in practice, for a five-year program. In fact, at the second level, the master degree, many more specialist aspects are included, particularly evident in the business aspects, where a better and more harmonious content distribution is observed. 
The study programs are different in the individual universities: this is not in itself a limit, but it certainly does not allow full comparability for specific purposes. We do not wish to make judgements about the overall preparation of the graduates, as this is not the aim of our study, but it should be underlined that the university preparation of future accountants differs according to geographical area. This is also a consequence of the fact that the state examinations for entry to the accounting profession are territorial, with territorial examining boards and examinations decided at local level: there is therefore a coherent approach but different results.

Furthermore, from the overall analysis, it can be observed that for the individual macro-subjects, the minimum and maximum values are very different from the mean, and this indicates that the structure of the program is affected by the different presence of the professors in the scientific-disciplinary sectors, the origin and development of which is profoundly rooted in the past.

This situation leads to a very mixed level of compliance of the study programs proposed with the provisions of the IES 2: the main knowledge areas are adequately represented especially in the business programs and all the more so when the degree course is specifically addressed to the accounting profession.

However, some subjects are substantially excluded from the education programs or play a marginal role: for example, IT and ethics. IT is mainly regarded as a technical element and not a work tool and is generally given little space in university economics and business degrees. Similarly, ethics is not widely taught as it is covered during training in the context of professional ethics. The same considerations apply to audit and assurance and taxation, which are normally given limited space as they are considered to be subjects of a highly technical and professional nature, and their application is studied in depth during the professional training phase.

Unfortunately, there is an excessive level of fragmentation in the relations between university and profession; recently, there have been some modest interventions but they have certainly not solved the problem. The connections, in many cases synergic, definitely exist at local level but efforts are required to ensure greater sharing of the education programs and the role of each player: revisions and updates are left more to the sensitivity of the degree course coordinators rather than deriving from a shared and discussed project.

What is most worrying is the neglect of issues related to ethics also in the light of the international debate on ESD. Given that the issues related to values and ethics are more evident during the training period, it would certainly be desirable to have a greater and more substantial cooperation between the profession and universities to ensure proper relevance also concerning this issue.

In more general terms, the policy implications arising from this initial study are therefore primarily addressed to the professional bodies and universities. Their goal must be to place at the centre of their agreement an educational program focused on accounting education for sustainable development, to be developed throughout the period of study and training of future professional accountants.

It is important to emphasize that ESD is not a particular programme or project, but is rather an umbrella for many forms of education that already exist, and new ones that remain to be created. ESD promotes efforts to rethink educational programmes and systems (both methods and contents) that currently support unsustainable societies. The essential characteristics of ESD can be implemented in many ways, so that ESD programmes reflect the unique environmental, social, cultural, and economic conditions of each locality. Furthermore, ESD increases civil capacity by enhancing and improving society, through a combination of formal, non-formal, and informal education. In this context, the IESs certainly play a key role. 
In conclusion, in order to foster the development of accounting education for sustainable development, it is essential for universities and professional bodies, which represent two cornerstones of accounting education, to collaborate in the study of a new way of spreading the accounting profession more consistent with the IESs and the internationally shared needs of global sustainability. This last consideration, pointing to Italy, can be extended to all those countries where accounting education depends on the close link between universities and professional bodies.

In the future, other IESs will be studied, in particular IES 3 (professional skills and general education) and IES 4 (professional values, ethics, and attitudes) and their diffusion both at university level and in professional practice in order to understand the education model prevalent in Italy for subsequent comparison with that of other European countries including the United Kingdom (Crawford et al., 2010).

\section{References}

Adler, R. W., Whiting, R. H., \& Wynn-Williams, K. (2004). Student-led and teacher-led case presentations: Empirical evidence about learning styles in an accounting course. Accounting Education: An International Journal, 13(2), 213-229.

Beattie, V., Fearnley, S., \& Hines, T. (2012). A real-life case study of audit interactions - resolving messy, complex problems. Accounting Education: An International Journal, 21(2), 111-129.

Black, J. (2008). Constructing and contesting legitimacy and accountability in polycentric regulatory regimes. Regulation \& Governance, 2(2), 137-164.

Boyce, G., Williams, S., Kelly, A., \& Yee, H. (2001). Fostering deep and elaborative learning and generic (soft) skill development: The strategic use of case studies in accounting education. Accounting Education: An International Journal, 10(1), 37-60.

Broadbent, J., \& Laughlin, R. (2005). Organisational and accounting change: Theoretical and empirical reflections and thoughts on a future research agenda. Journal of Accounting \& Organisational Change, 1(1), 7-25.

Cooper, C., Neu, D., \& Lehman, G. (2003). Globalisation and its discontents: A concern about growth and globalization. Accounting Forum, 27(4), 359-364.

Cooper, D. J., \& Robson, K. (2006). Accounting, professions and regulation: Locating sites of professionalization. Accounting, Organisations, and Society, 31(4-5), 415-444.

Crawford, L., Helliar, C., Monk, E., \& Veneziani, M. (2014). International Accounting Education Standards Board: Organisational legitimacy within the field of professional accountancy education. Accounting Forum, 38(1), 67-89.

Crawford, L., Helliar, C., Monk, E., Mina, M., Teodori, C., Veneziani, M., Wanyama, S., \& Falgi, K. (2010). IES compliance and the knowledge, skills and values of IES 2, 3 and 4. Final Report, the International Association for Accounting Education \& Research. Retrieved from http://www.iaaer.org/research_grants/files/Final_report_Helliar[1].pdf

Daff, L. (2012). Lessons from successes in medical communication training and their applications to accounting education. Accounting Education: An International Journal, 21(4), 385-405.

Everett, J. (2003). Globalization and its new spaces for (alternative) accounting research. Accounting Forum, 27(4), 400-424.

Graham, C., \& Neu, D. (2003). Accounting for globalization. Accounting Forum, 27(4), 449-471.

Hall, L. A., \& Sen, J. (2004). Harmonizing international qualifications of accountants: Steps toward reciprocity in a global profession. Journal of Accounting \& Finance Research, 12(5), 104-117.

Hargreaves, A. (2003). Teaching in the knowledge society: Education in the age of insecurity. New York, NY: Teachers College Press.

Helliar, C. V., Michaelson, R., Power, D. M., \& Sinclair, C. D. (2000). Using a portfolio management game (Finesse) to teach finance. Accounting Education: An International Journal, 9(1), 37-51.

Howieson, B. (2003). Accounting practice in the new millennium: Is accounting education ready to meet the challenge? British Accounting Review, 35(2), 69-103.

Humphrey, C., Kausar, A., Loft, A., \& Woods, M. (2011). Regulating audit beyond the crisis: A critical discussion of the EU green paper. European Accounting Review, 20(3), 431-457.

Humphrey, C., Loft, A., \& Woods, M. (2009). The global audit profession and the international financial architecture: Understanding the regulatory relationships at a time of financial crisis. Accounting, Organizations and Society, 34(6-7), 810-825. 
International Federation of Accountants [IFAC]. (2010a). Handbook of international education pronouncements. IFAC Publication, New York.

International Federation of Accountants [IFAC]. (2010b). IAESB 2010-2013 strategy and work plan. IFAC Publication, New York. International Federation of Accountants [IFAC]. (2016). Retrieved from http://www.ifac.org/about-ifac

Lehman, G. (2005). A critical perspective on the harmonisation of accounting in a globalising world. Critical Perspectives on Accounting, 16(7), 975-992.

Lehman, G. (2009). Globalisation and the internationalisation of accounting: New technologies, instrumentalism and harmonisation. Critical Perspectives on Accounting, 20(4), 445-447.

Loft, A., Humphrey, C., \& Turley, S. (2006). In pursuit of global regulation: Changing governance and accountability structures at the International Federation of Accountants (IFAC). Accounting, Auditing \& Accountability Journal, 19(3), 428-451.

Murgatroyd, S. (2010). 'Wicked problems' and the work of the school. European Journal of Education, 45(2), 259-279.

Needles, B. E. (2008). International Education Standards (IES): Issues of implementation - A report on the third IAAER globalization roundtable. Accounting Education: An International Journal, 17(1), S69-S79.

Needles, B. E., Kantor, J., \& Shoenthal, E. R. (1992). Global compliance with international accounting education guidelines. Accounting Education: An International Journal, 1(3), 211-224.

Sahlberg, P., \& Oldroyd, D. (2010). Pedagogy for economic competitiveness and sustainable development. European Journal of Education, 45(2), 280-299.

Sikka, P., Haslam, C., Kyriacou, O., \& Agrizzi, D. (2007). Professionalizing claims and the state of UK professional accounting education: Some evidence. Accounting Education: An International Journal, 16(1), 3-22.

Sterling, S. (2001). Sustainable education: Re-visioning learning and change. Schumacher Briefing No. 6, Green Books, Dartington.

Suddaby, R., Gendron, Y., \& Lam, H. (2009). The organisational context of professionalism in accounting. Accounting, Organizations and Society, 34(3-4), 409-427.

Veneziani, M. (2012). L'accounting education: osservazioni preliminari sul caso italiano. Milano: Franco Angeli. 


\section{Appendix A}

Panel 1: Undergraduate Degrees L18

Table A1

Macro-subjects

\begin{tabular}{|c|c|c|c|c|c|c|c|c|c|c|c|}
\hline \multirow[b]{2}{*}{ Macro-subject } & \multicolumn{5}{|c|}{ Aggregate value } & \multicolumn{2}{|c|}{ Aggregate value (\%) } & \multicolumn{4}{|c|}{ Min. and max. value (\%) } \\
\hline & $\begin{array}{l}\text { Total } \\
\text { no. of } \\
\text { subjects }\end{array}$ & $\begin{array}{l}\text { Total } \\
\text { MEC }\end{array}$ & $\begin{array}{l}\text { Mean } \\
\text { no. of } \\
\text { subjects }\end{array}$ & $\begin{array}{l}\text { Mean } \\
\text { MEC }\end{array}$ & $\begin{array}{l}\text { Mean } \\
\text { MEC } \\
\text { per } \\
\text { subject }\end{array}$ & $\begin{array}{l}\text { Total } \\
\text { no. of } \\
\text { subjects }\end{array}$ & $\begin{array}{l}\text { Total } \\
\text { MEC }\end{array}$ & $\begin{array}{l}\text { Min. } \\
\text { no. of } \\
\text { subjects } \\
(\%)\end{array}$ & $\begin{array}{l}\text { Min. } \\
\text { MEC } \\
(\%)\end{array}$ & $\begin{array}{l}\text { Max. } \\
\text { no. of } \\
\text { subjects } \\
(\%)\end{array}$ & $\begin{array}{l}\text { Max. } \\
\text { MEC } \\
\text { (\%) }\end{array}$ \\
\hline $\begin{array}{l}\text { Financial accounting } \\
\text { and reporting }\end{array}$ & 307.00 & $2,745.00$ & 2.04 & 18.51 & 8.94 & 12.05 & 13.66 & 5.26 & 6.12 & 21.05 & 26.00 \\
\hline $\begin{array}{l}\text { Management } \\
\text { accounting and control }\end{array}$ & 98.00 & 765.00 & 0.66 & 5.18 & 7.81 & 3.85 & 3.81 & 0.00 & 0.00 & 12.50 & 10.98 \\
\hline Taxation & 22.00 & 161.00 & 0.19 & 1.41 & 7.32 & 0.86 & 0.80 & 0.00 & 0.00 & 7.14 & 7.38 \\
\hline $\begin{array}{l}\text { Business and } \\
\text { commercial law }\end{array}$ & 496.00 & $3,963.00$ & 3.38 & 27.13 & 7.99 & 19.47 & 19.73 & 12.50 & 9.84 & 29.17 & 33.78 \\
\hline Audit and assurance & 10.00 & 77.00 & 0.07 & 0.53 & 7.70 & 0.39 & 0.38 & 0.00 & 0.00 & 4.00 & 6.25 \\
\hline $\begin{array}{l}\text { Finance and financial } \\
\text { management }\end{array}$ & 100.00 & 733.00 & 0.70 & 5.03 & 7.33 & 3.93 & 3.65 & 0.00 & 0.00 & 17.39 & 16.22 \\
\hline Financial markets & 96.00 & 730.00 & 0.64 & 4.95 & 7.60 & 3.77 & 3.63 & 0.00 & 0.00 & 18.18 & 16.44 \\
\hline Economics & 412.00 & $3,451.00$ & 2.88 & 24.20 & 8.38 & 16.18 & 17.18 & 7.14 & 7.50 & 30.00 & 29.41 \\
\hline Business environment & 54.00 & 380.00 & 0.40 & 2.67 & 7.04 & 2.12 & 1.89 & 0.00 & 0.00 & 11.76 & 12.50 \\
\hline $\begin{array}{l}\text { International business } \\
\text { and globalisation }\end{array}$ & 11.00 & 86.00 & 0.05 & 0.41 & 7.82 & 0.43 & 0.43 & 0.00 & 0.00 & 11.11 & 26.79 \\
\hline Corporate governance & 1.00 & 8.00 & 0.01 & 0.05 & 8.00 & 0.04 & 0.04 & 0.00 & 0.00 & 5.56 & 5.71 \\
\hline Business ethics & 14.00 & 83.00 & 0.09 & 0.54 & 5.93 & 0.55 & 0.41 & 0.00 & 0.00 & 5.56 & 5.53 \\
\hline $\begin{array}{l}\text { Organizational } \\
\text { behavior }\end{array}$ & 64.00 & 434.00 & 0.45 & 3.08 & 6.78 & 2.51 & 2.16 & 0.00 & 0.00 & 7.69 & 8.00 \\
\hline $\begin{array}{l}\text { Management and } \\
\text { strategic } \\
\text { decision-making }\end{array}$ & 212.00 & $1,689.00$ & 1.35 & 11.27 & 7.97 & 8.32 & 8.41 & 0.00 & 0.00 & 25.00 & 26.00 \\
\hline Marketing & 95.00 & 720.00 & 0.66 & 4.98 & 7.58 & 3.73 & 3.58 & 0.00 & 0.00 & 21.05 & 13.33 \\
\hline IT general knowledge & 111.00 & 452.00 & 0.78 & 3.06 & 4.07 & 4.36 & 2.25 & 0.00 & 0.00 & 6.25 & 5.11 \\
\hline IT control knowledge & 2.00 & 10.00 & 0.01 & 0.05 & 5.00 & 0.08 & 0.05 & 0.00 & 0.00 & 5.26 & 2.63 \\
\hline IT control competences & 1.00 & 10.00 & 0.01 & 0.06 & 10.00 & 0.04 & 0.05 & 0.00 & 0.00 & 5.56 & 6.71 \\
\hline IT user competences & 6.00 & 30.00 & 0.04 & 0.23 & 5.00 & 0.24 & 0.15 & 0.00 & 0.00 & 5.88 & 6.12 \\
\hline $\begin{array}{l}\text { Designer of } \\
\text { information systems }\end{array}$ & 6.00 & 38.00 & 0.03 & 0.21 & 6.33 & 0.24 & 0.19 & 0.00 & 0.00 & 5.26 & 4.08 \\
\hline $\begin{array}{l}\text { Professional values } \\
\text { and ethics }\end{array}$ & 14.00 & 43.00 & 0.05 & 0.18 & 3.07 & 0.55 & 0.21 & 0.00 & 0.00 & 8.33 & 4.88 \\
\hline Quantitative methods & 415.00 & $3,483.00$ & 3.07 & 23.55 & 8.39 & 16.29 & 17.34 & 12.50 & 15.38 & 29.41 & 32.64 \\
\hline Total value & $2,547.00$ & $20,091.00$ & 17.56 & 137.28 & 7.89 & 100.00 & 100.00 & & & & \\
\hline
\end{tabular}

Table A2

Knowledge Areas

\begin{tabular}{|c|c|c|c|c|c|c|c|}
\hline \multirow[b]{2}{*}{ Knowledge area } & \multicolumn{5}{|c|}{ Aggregate value } & \multicolumn{2}{|c|}{ Aggregate value (\%) } \\
\hline & $\begin{array}{l}\text { Total number } \\
\text { of subjects }\end{array}$ & Total MEC & $\begin{array}{l}\text { Mean number } \\
\text { of subjects }\end{array}$ & Mean MEC & $\begin{array}{l}\text { Mean MEC } \\
\text { per subject }\end{array}$ & $\begin{array}{l}\text { Total number } \\
\text { of subjects }\end{array}$ & Total MEC \\
\hline Business administration & 983.00 & $7,901.00$ & 6.59 & 53.58 & 8.04 & 38.59 & 39.33 \\
\hline Economics & 499.00 & $4,078.00$ & 3.51 & 28.69 & 8.17 & 19.59 & 20.30 \\
\hline Business and law & 496.00 & $3,963.00$ & 3.38 & 27.13 & 7.99 & 19.47 & 19.73 \\
\hline Ethics & 28.00 & 126.00 & 0.14 & 0.71 & 4.50 & 1.11 & 0.62 \\
\hline IT & 126.00 & 540.00 & 0.87 & 3.62 & 4.29 & 4.95 & 2.68 \\
\hline Mathematics & 415.00 & $3,483.00$ & 3.07 & 23.55 & 8.39 & 16.29 & 17.34 \\
\hline Total value & $2,547.00$ & $20,091.00$ & 17.56 & 137.28 & 7.89 & 100.00 & 100.00 \\
\hline
\end{tabular}




\section{Appendix B}

Panel 2: Undergraduate Degrees L33

Table B1

Macro-subjects

\begin{tabular}{|c|c|c|c|c|c|c|c|c|c|c|c|}
\hline \multirow[b]{2}{*}{ Macro-subject } & \multicolumn{5}{|c|}{ Aggregate value } & \multicolumn{2}{|c|}{ Aggregate value (\%) } & \multicolumn{4}{|c|}{ Min. and max. value (\%) } \\
\hline & $\begin{array}{l}\text { Total } \\
\text { no. of } \\
\text { subjects }\end{array}$ & $\begin{array}{l}\text { Total } \\
\text { MEC }\end{array}$ & $\begin{array}{l}\text { Mean } \\
\text { no. of } \\
\text { subjects }\end{array}$ & $\begin{array}{l}\text { Mean } \\
\text { MEC }\end{array}$ & $\begin{array}{l}\text { Mean } \\
\text { MEC } \\
\text { per } \\
\text { subject }\end{array}$ & $\begin{array}{l}\text { Total } \\
\text { no. of } \\
\text { subjects }\end{array}$ & $\begin{array}{l}\text { Total } \\
\text { MEC }\end{array}$ & $\begin{array}{l}\text { Min. } \\
\text { no. of } \\
\text { subjects } \\
(\%)\end{array}$ & $\begin{array}{l}\text { Min. } \\
\text { MEC } \\
(\%)\end{array}$ & $\begin{array}{l}\text { Max. } \\
\text { no. of } \\
\text { subjects } \\
(\%)\end{array}$ & $\begin{array}{l}\text { Max. } \\
\text { MEC } \\
(\%)\end{array}$ \\
\hline $\begin{array}{l}\text { Financial accounting } \\
\text { and reporting }\end{array}$ & 112.00 & $1,012.00$ & 1.62 & 14.90 & 9.04 & 9.35 & 10.57 & 5.26 & 5.37 & 9.52 & 14.29 \\
\hline $\begin{array}{l}\text { Management accounting } \\
\text { and control }\end{array}$ & 9.00 & 64.00 & 0.13 & 0.97 & 7.11 & 0.75 & 0.67 & 0.00 & 0.00 & 9.52 & 5.66 \\
\hline Taxation & 39.00 & 313.00 & 0.55 & 4.42 & 8.03 & 3.26 & 3.27 & 0.00 & 0.00 & 5.00 & 8.00 \\
\hline $\begin{array}{l}\text { Business and } \\
\text { commercial law }\end{array}$ & 210.00 & $1,677.00$ & 3.06 & 24.70 & 7.99 & 17.53 & 17.51 & 11.11 & 11.11 & 19.05 & 22.86 \\
\hline Audit and assurance & 2.00 & 14.00 & 0.01 & 0.10 & 7.00 & 0.17 & 0.15 & 0.00 & 0.00 & 5.88 & 5.88 \\
\hline $\begin{array}{l}\text { Finance and financial } \\
\text { management }\end{array}$ & 16.00 & 125.00 & 0.23 & 1.81 & 7.81 & 1.34 & 1.31 & 0.00 & 0.00 & 10.53 & 12.00 \\
\hline Financial markets & 37.00 & 297.00 & 0.54 & 4.32 & 8.03 & 3.09 & 3.10 & 0.00 & 0.00 & 15.79 & 16.33 \\
\hline Economics & 331.00 & $2,738.00$ & 4.92 & 40.37 & 8.27 & 27.63 & 28.59 & 9.09 & 8.70 & 44.44 & 51.11 \\
\hline Business environment & 36.00 & 267.00 & 0.49 & 3.65 & 7.42 & 3.01 & 2.79 & 0.00 & 0.00 & 13.64 & 16.23 \\
\hline $\begin{array}{l}\text { International business } \\
\text { and globalisation }\end{array}$ & 8.00 & 67.00 & 0.13 & 1.05 & 8.38 & 0.67 & 0.70 & 0.00 & 0.00 & 6.25 & 6.67 \\
\hline Corporate governance & 0.00 & 0.00 & 0.00 & 0.00 & 0.00 & 0.00 & 0.00 & 0.00 & 0.00 & 0.00 & 0.00 \\
\hline Business ethics & 2.00 & 16.00 & 0.05 & 0.40 & 8.00 & 0.17 & 0.17 & 0.00 & 0.00 & 9.09 & 10.39 \\
\hline Organizational behavior & 12.00 & 86.00 & 0.19 & 1.39 & 7.17 & 1.00 & 0.90 & 0.00 & 0.00 & 11.11 & 10.64 \\
\hline $\begin{array}{l}\text { Management and } \\
\text { strategic } \\
\text { decision-making }\end{array}$ & 48.00 & 378.00 & 0.79 & 6.30 & 7.88 & 4.01 & 3.95 & 0.00 & 0.00 & 11.11 & 12.24 \\
\hline Marketing & 8.00 & 60.00 & 0.07 & 0.58 & 7.50 & 0.67 & 0.62 & 0.00 & 0.00 & 5.26 & 6.76 \\
\hline General knowledge of IT & 53.00 & 201.00 & 0.80 & 3.30 & 3.79 & 4.42 & 2.10 & 0.00 & 0.00 & 4.76 & 5.71 \\
\hline IT control knowledge & 1.00 & 9.00 & 0.01 & 0.08 & 9.00 & 0.08 & 0.09 & 0.00 & 0.00 & 4.76 & 5.66 \\
\hline IT control competences & 0.00 & 0.00 & 0.00 & 0.00 & 0.00 & 0.00 & 0.00 & 0.00 & 0.00 & 0.00 & 0.00 \\
\hline IT user competences & 1.00 & 9.00 & 0.01 & 0.08 & 9.00 & 0.08 & 0.08 & 0.00 & 0.00 & 6.25 & 6.67 \\
\hline $\begin{array}{l}\text { Designer of information } \\
\text { systems }\end{array}$ & 6.00 & 39.00 & 0.04 & 0.33 & 6.50 & 0.49 & 0.40 & 0.00 & 0.00 & 23.81 & 20.75 \\
\hline $\begin{array}{l}\text { Professional values and } \\
\text { ethics }\end{array}$ & 1.00 & 3.00 & 0.03 & 0.08 & 3.00 & 0.08 & 0.03 & 0.00 & 0.00 & 4.55 & 1.95 \\
\hline Quantitative methods & 266.00 & $2,203.00$ & 4.02 & 32.86 & 8.28 & 22.20 & 23.00 & 12.50 & 13.33 & 36.84 & 34.00 \\
\hline Total value & $1,198.00$ & $9,578.00$ & 17.69 & 141.69 & 7.99 & 100.00 & 100.00 & & & & \\
\hline
\end{tabular}

Table B2

Knowledge Areas

\begin{tabular}{|c|c|c|c|c|c|c|c|}
\hline \multirow[b]{2}{*}{ Knowledge area } & \multicolumn{5}{|c|}{ Aggregate value } & \multicolumn{2}{|c|}{ Aggregate value (\%) } \\
\hline & $\begin{array}{l}\begin{array}{l}\text { Total number } \\
\text { of subjects }\end{array} \\
\end{array}$ & Total MEC & $\begin{array}{l}\text { Mean number } \\
\text { of subjects }\end{array}$ & Mean MEC & $\begin{array}{l}\text { Mean MEC } \\
\text { per subject }\end{array}$ & $\begin{array}{l}\text { Total number } \\
\text { of subjects }\end{array}$ & Total MEC \\
\hline Business administration & 244.00 & $2,036.00$ & 3.59 & 30.38 & 8.34 & 20.37 & 21.26 \\
\hline Economics & 414.00 & $3,385.00$ & 6.08 & 49.49 & 8.18 & 34.56 & 35.34 \\
\hline Business and law & 210.00 & $1,677.00$ & 3.06 & 24.70 & 7.99 & 17.53 & 17.51 \\
\hline Ethics & 3.00 & 19.00 & 0.07 & 0.48 & 6.33 & 0.25 & 0.20 \\
\hline IT & 61.00 & 258.00 & 0.87 & 3.78 & 4.23 & 5.09 & 2.69 \\
\hline Mathematics & 266.00 & $2,203.00$ & 4.02 & 32.86 & 8.28 & 22.20 & 23.00 \\
\hline Total value & $1,198.00$ & $9,578.00$ & 17.69 & 141.69 & 7.99 & 100.00 & 100.00 \\
\hline
\end{tabular}




\section{Appendix C}

Panel 3: Master Degrees L77

Table C1

Macro-subjects

\begin{tabular}{|c|c|c|c|c|c|c|c|c|c|c|c|}
\hline \multirow[b]{2}{*}{ Macro-subject } & \multicolumn{5}{|c|}{ Aggregate value } & \multicolumn{2}{|c|}{ Aggregate value (\%) } & \multicolumn{4}{|c|}{ Min. and max. value (\%) } \\
\hline & $\begin{array}{l}\text { Total } \\
\text { no. of } \\
\text { subjects }\end{array}$ & $\begin{array}{l}\text { Total } \\
\text { MEC }\end{array}$ & $\begin{array}{l}\text { Mean } \\
\text { no. of } \\
\text { subjects }\end{array}$ & $\begin{array}{l}\text { Mean } \\
\text { MEC }\end{array}$ & $\begin{array}{l}\text { Mean } \\
\text { MEC } \\
\text { per } \\
\text { subject }\end{array}$ & $\begin{array}{l}\text { Total } \\
\text { no. of } \\
\text { subjects }\end{array}$ & $\begin{array}{l}\text { Total } \\
\text { MEC }\end{array}$ & $\begin{array}{l}\text { Min. } \\
\text { no. of } \\
\text { subjects } \\
(\%)\end{array}$ & $\begin{array}{l}\text { Min. } \\
\text { MEC } \\
(\%)\end{array}$ & $\begin{array}{l}\text { Max. } \\
\text { no. of } \\
\text { subjects } \\
(\%)\end{array}$ & $\begin{array}{l}\text { Max. } \\
\text { MEC } \\
(\%)\end{array}$ \\
\hline $\begin{array}{l}\text { Financial accounting } \\
\text { and reporting }\end{array}$ & 236.00 & $1,903.00$ & 1.11 & 9.06 & 8.06 & 10.81 & 11.87 & 0.00 & 0.00 & 63.64 & 56.67 \\
\hline $\begin{array}{l}\text { Management } \\
\text { accounting and control }\end{array}$ & 98.00 & 711.00 & 0.50 & 3.48 & 7.26 & 4.49 & 4.44 & 0.00 & 0.00 & 14.29 & 15.96 \\
\hline Taxation & 19.00 & 163.00 & 0.08 & 0.67 & 8.58 & 0.87 & 1.02 & 0.00 & 0.00 & 10.00 & 15.00 \\
\hline $\begin{array}{l}\text { Business and } \\
\text { commercial law }\end{array}$ & 352.00 & $2,375.00$ & 1.85 & 11.90 & 6.75 & 16.12 & 14.82 & 0.00 & 0.00 & 46.67 & 37.50 \\
\hline Audit and assurance & 21.00 & 163.00 & 0.09 & 0.72 & 7.76 & 0.96 & 1.02 & 0.00 & 0.00 & 22.22 & 25.00 \\
\hline $\begin{array}{l}\text { Finance and financial } \\
\text { management }\end{array}$ & 142.00 & 994.00 & 0.84 & 5.83 & 7.00 & 6.50 & 6.20 & 0.00 & 0.00 & 23.08 & 23.08 \\
\hline Financial markets & 47.00 & 362.00 & 0.24 & 1.97 & 7.70 & 2.15 & 2.26 & 0.00 & 0.00 & 28.57 & 28.57 \\
\hline Economics & 250.00 & $1,818.00$ & 1.25 & 9.11 & 7.27 & 11.45 & 11.34 & 0.00 & 0.00 & 45.45 & 50.00 \\
\hline Business environment & 61.00 & 487.00 & 0.29 & 2.27 & 7.98 & 2.79 & 3.04 & 0.00 & 0.00 & 25.00 & 21.69 \\
\hline $\begin{array}{l}\text { International business } \\
\text { and globalisation }\end{array}$ & 83.00 & 681.00 & 0.41 & 3.47 & 8.20 & 3.80 & 4.25 & 0.00 & 0.00 & 33.33 & 39.51 \\
\hline Corporate governance & 49.00 & 341.00 & 0.26 & 1.63 & 6.96 & 2.24 & 2.13 & 0.00 & 0.00 & 16.67 & 14.81 \\
\hline Business ethics & 35.00 & 273.00 & 0.19 & 1.52 & 7.80 & 1.60 & 1.70 & 0.00 & 0.00 & 18.18 & 20.00 \\
\hline $\begin{array}{l}\text { Organizational } \\
\text { behavior }\end{array}$ & 71.00 & 540.00 & 0.32 & 2.54 & 7.61 & 3.25 & 3.37 & 0.00 & 0.00 & 16.67 & 22.22 \\
\hline $\begin{array}{l}\text { Management and } \\
\text { strategic } \\
\text { decision-making }\end{array}$ & 305.00 & $2,300.00$ & 1.63 & 12.23 & 7.54 & 13.97 & 14.35 & 0.00 & 0.00 & 50.00 & 42.86 \\
\hline Marketing & 132.00 & $1,015.00$ & 0.57 & 4.55 & 7.69 & 6.05 & 6.33 & 0.00 & 0.00 & 40.00 & 40.19 \\
\hline IT general knowledge & 4.00 & 8.00 & 0.02 & 0.03 & 2.00 & 0.19 & 0.04 & 0.00 & 0.00 & 20.00 & 6.10 \\
\hline IT control knowledge & 1.00 & 6.00 & 0.02 & 0.11 & 6.00 & 0.06 & 0.04 & 0.00 & 0.00 & 9.09 & 6.67 \\
\hline IT control competences & 0.00 & 0.00 & 0.00 & 0.00 & 0.00 & 0.00 & 0.00 & 0.00 & 0.00 & 0.00 & 0.00 \\
\hline IT user competences & 8.00 & 55.00 & 0.03 & 0.21 & 6.88 & 0.37 & 0.34 & 0.00 & 0.00 & 6.67 & 8.41 \\
\hline $\begin{array}{l}\text { Designer of } \\
\text { information systems }\end{array}$ & 7.00 & 43.00 & 0.05 & 0.22 & 6.14 & 0.33 & 0.26 & 0.00 & 0.00 & 7.69 & 8.82 \\
\hline $\begin{array}{l}\text { Professional values } \\
\text { and ethics }\end{array}$ & 26.00 & 114.00 & 0.09 & 0.44 & 4.38 & 1.19 & 0.71 & 0.00 & 0.00 & 16.67 & 11.11 \\
\hline Quantitative methods & 236.00 & $1,678.00$ & 1.24 & 8.67 & 7.11 & 10.81 & 10.47 & 0.00 & 0.00 & 33.33 & 33.33 \\
\hline Total value & $2,183.00$ & $16,030.00$ & 11.08 & 80.63 & 7.34 & 100.00 & 100.00 & & & & \\
\hline
\end{tabular}

Table C2

Knowledge Areas

\begin{tabular}{|c|c|c|c|c|c|c|c|}
\hline \multirow[b]{2}{*}{ Knowledge area } & \multicolumn{5}{|c|}{ Aggregate value } & \multicolumn{2}{|c|}{ Aggregate value (\%) } \\
\hline & $\begin{array}{l}\text { Total number } \\
\text { of subjects }\end{array}$ & Total MEC & $\begin{array}{l}\text { Mean number } \\
\text { of subjects }\end{array}$ & Mean MEC & $\begin{array}{l}\text { Mean MEC } \\
\text { per subject }\end{array}$ & $\begin{array}{l}\text { Total number } \\
\text { of subjects }\end{array}$ & Total MEC \\
\hline Business administration & $1,101.00$ & $8,329.00$ & 5.57 & 41.99 & 7.56 & 50.44 & 51.96 \\
\hline Economics & 413.00 & $3,149.00$ & 2.03 & 15.52 & 7.62 & 18.92 & 19.64 \\
\hline Business and law & 352.00 & $2,375.00$ & 1.85 & 11.90 & 6.75 & 16.12 & 14.82 \\
\hline Ethics & 61.00 & 387.00 & 0.28 & 1.97 & 6.34 & 2.79 & 2.41 \\
\hline IT & 20.00 & 112.00 & 0.11 & 0.58 & 5.60 & 0.92 & 0.70 \\
\hline Mathematics & 236.00 & $1,678.00$ & 1.24 & 8.67 & 7.11 & 10.81 & 10.47 \\
\hline Total value & $2,183.00$ & $16,030.00$ & 11.08 & 80.63 & 7.34 & 100.00 & 100.00 \\
\hline
\end{tabular}




\section{Appendix D}

Panel 4: Master Degrees L56

Table D1

Macro-subjects

\begin{tabular}{|c|c|c|c|c|c|c|c|c|c|c|c|}
\hline \multirow[b]{2}{*}{ Macro-subject } & \multicolumn{5}{|c|}{ Aggregate value } & \multicolumn{2}{|c|}{ Aggregate value (\%) } & \multicolumn{4}{|c|}{ Min. and max. value (\%) } \\
\hline & $\begin{array}{l}\text { Total } \\
\text { no. of } \\
\text { subjects }\end{array}$ & $\begin{array}{l}\text { Total } \\
\text { MEC }\end{array}$ & $\begin{array}{l}\text { Mean } \\
\text { no. of } \\
\text { subjects }\end{array}$ & $\begin{array}{l}\text { Mean } \\
\text { MEC }\end{array}$ & $\begin{array}{l}\text { Mean } \\
\text { MEC } \\
\text { per } \\
\text { subject }\end{array}$ & $\begin{array}{l}\text { Total } \\
\text { no. of } \\
\text { subjects }\end{array}$ & $\begin{array}{l}\text { Total } \\
\text { MEC }\end{array}$ & $\begin{array}{l}\text { Min. } \\
\text { no. of } \\
\text { subjects } \\
(\%)\end{array}$ & $\begin{array}{l}\text { Min. } \\
\text { MEC } \\
(\%)\end{array}$ & $\begin{array}{l}\text { Max. } \\
\text { no. of } \\
\text { subjects } \\
(\%)\end{array}$ & $\begin{array}{l}\text { Max. } \\
\text { MEC } \\
\text { (\%) }\end{array}$ \\
\hline $\begin{array}{l}\text { Financial accounting } \\
\text { and reporting }\end{array}$ & 34.00 & 258.00 & 0.45 & 3.38 & 7.59 & 3.93 & 3.81 & 0.00 & 0.00 & 27.27 & 26.67 \\
\hline $\begin{array}{l}\text { Management accounting } \\
\text { and control }\end{array}$ & 13.00 & 87.00 & 0.14 & 1.01 & 6.69 & 1.50 & 1.28 & 0.00 & 0.00 & 27.27 & 20.00 \\
\hline Taxation & 8.00 & 59.00 & 0.11 & 0.77 & 7.38 & 0.92 & 0.87 & 0.00 & 0.00 & 11.11 & 10.99 \\
\hline $\begin{array}{l}\text { Business and } \\
\text { commercial law }\end{array}$ & 128.00 & 965.00 & 1.49 & 10.99 & 7.54 & 14.80 & 14.25 & 0.00 & 0.00 & 40.00 & 42.86 \\
\hline Audit and assurance & 10.00 & 85.00 & 0.14 & 1.22 & 8.50 & 1.16 & 1.26 & 0.00 & 0.00 & 18.18 & 23.33 \\
\hline $\begin{array}{l}\text { Finance and financial } \\
\text { management }\end{array}$ & 27.00 & 205.00 & 0.28 & 2.13 & 7.59 & 3.12 & 3.03 & 0.00 & 0.00 & 18.18 & 21.51 \\
\hline Financial markets & 33.00 & 277.00 & 0.46 & 3.86 & 8.39 & 3.82 & 4.09 & 0.00 & 0.00 & 27.27 & 29.03 \\
\hline Economics & 244.00 & $1,967.00$ & 2.84 & 22.25 & 8.06 & 28.21 & 29.05 & 0.00 & 0.00 & 66.67 & 63.33 \\
\hline Business environment & 51.00 & 384.00 & 0.69 & 4.96 & 7.41 & 5.90 & 5.67 & 0.00 & 0.00 & 27.27 & 25.00 \\
\hline $\begin{array}{l}\text { International business } \\
\text { and globalisation }\end{array}$ & 43.00 & 346.00 & 0.56 & 4.39 & 8.05 & 4.97 & 5.11 & 0.00 & 0.00 & 36.36 & 37.50 \\
\hline Corporate governance & 2.00 & 17.00 & 0.02 & 0.17 & 8.50 & 0.23 & 0.25 & 0.00 & 0.00 & 9.09 & 10.00 \\
\hline Business ethics & 8.00 & 57.00 & 0.08 & 0.49 & 7.13 & 0.92 & 0.84 & 0.00 & 0.00 & 20.00 & 20.00 \\
\hline Organizational behavior & 5.00 & 36.00 & 0.07 & 0.52 & 7.20 & 0.58 & 0.53 & 0.00 & 0.00 & 6.67 & 8.57 \\
\hline $\begin{array}{l}\text { Management and } \\
\text { strategic } \\
\text { decision-making }\end{array}$ & 60.00 & 462.00 & 0.65 & 4.99 & 7.70 & 6.94 & 6.82 & 0.00 & 0.00 & 45.45 & 45.33 \\
\hline Marketing & 12.00 & 102.00 & 0.13 & 1.14 & 8.50 & 1.39 & 1.51 & 0.00 & 0.00 & 20.00 & 20.00 \\
\hline General knowledg & 3.00 & 18.00 & 0.04 & 0.26 & 6.00 & 0.35 & 0.27 & 0.00 & 0.00 & 8.33 & 7.41 \\
\hline IT control knowledge & 0.00 & 0.00 & 0.00 & 0.00 & 0.00 & 0.00 & 0.00 & 0.00 & 0.00 & 0.00 & 0.00 \\
\hline IT control competences & 0.00 & 0.00 & 0.00 & 0.00 & 0.00 & 0.00 & 0.00 & 0.00 & 0.00 & 0.00 & 0.00 \\
\hline IT user competences & 0.00 & 0.00 & 0.00 & 0.00 & 0.00 & 0.00 & 0.00 & 0.00 & 0.00 & 0.00 & 0.00 \\
\hline $\begin{array}{l}\text { Designer of information } \\
\text { systems }\end{array}$ & 4.00 & 33.00 & 0.05 & 0.43 & 8.25 & 0.45 & 0.49 & 0.00 & 0.00 & 11.11 & 11.54 \\
\hline $\begin{array}{l}\text { Professional values and } \\
\text { ethics }\end{array}$ & 2.00 & 14.00 & 0.03 & 0.13 & 7.00 & 0.23 & 0.21 & 0.00 & 0.00 & 12.50 & 15.38 \\
\hline Quantitative methods & 178.00 & $1,399.00$ & 2.13 & 16.63 & 7.86 & 20.58 & 20.66 & 0.00 & 0.00 & 46.15 & 43.01 \\
\hline Total value & 865.00 & $6,771.00$ & 10.36 & 79.72 & 7.83 & 100.00 & 100.00 & & & & \\
\hline
\end{tabular}

Table D2

Knowledge Areas

\begin{tabular}{|c|c|c|c|c|c|c|c|}
\hline \multirow[b]{2}{*}{ Knowledge area } & \multicolumn{5}{|c|}{ Aggregate value } & \multicolumn{2}{|c|}{ Aggregate value (\%) } \\
\hline & $\begin{array}{l}\text { Total number } \\
\text { of subjects }\end{array}$ & Total MEC & $\begin{array}{l}\text { Mean number } \\
\text { of subjects }\end{array}$ & Mean MEC & $\begin{array}{l}\text { Mean MEC } \\
\text { per subject }\end{array}$ & $\begin{array}{l}\text { Total number } \\
\text { of subjects }\end{array}$ & Total MEC \\
\hline Business administration & 196.00 & $1,529.00$ & 2.34 & 18.42 & 7.87 & 22.66 & 22.58 \\
\hline Economics & 346.00 & $2,756.00$ & 4.19 & 32.38 & 7.72 & 40.00 & 40.70 \\
\hline Business and law & 128.00 & 965.00 & 1.49 & 10.99 & 7.37 & 14.80 & 14.25 \\
\hline Ethics & 10.00 & 71.00 & 0.12 & 0.61 & 5.67 & 1.16 & 1.05 \\
\hline IT & 7.00 & 51.00 & 0.09 & 0.69 & 7.36 & 0.80 & 0.76 \\
\hline Mathematics & 178.00 & $1,399.00$ & 2.13 & 16.63 & 7.80 & 20.58 & 20.66 \\
\hline Total value & 865.00 & $6,771.00$ & 10.36 & 79.72 & 7.83 & 100.00 & 100.00 \\
\hline
\end{tabular}




\section{Appendix E}

Panel 5: Five-Year Degrees L18+L77

Table E1

Macro-subjects

\begin{tabular}{|c|c|c|c|c|c|c|c|}
\hline \multirow[b]{2}{*}{ Macro-subject } & \multicolumn{5}{|c|}{ Aggregate value } & \multicolumn{2}{|c|}{ Aggregate value (\%) } \\
\hline & $\begin{array}{l}\text { Total no. } \\
\text { of subjects }\end{array}$ & Total MEC & $\begin{array}{l}\text { Mean no. } \\
\text { of subjects }\end{array}$ & Mean MEC & $\begin{array}{l}\text { Mean MEC } \\
\text { per subject }\end{array}$ & $\begin{array}{l}\text { Total no. } \\
\text { of subjects }\end{array}$ & Total MEC \\
\hline $\begin{array}{l}\text { Financial accounting and } \\
\text { reporting }\end{array}$ & 543.00 & $4,648.00$ & 3.15 & 27.57 & 8.74 & 11.48 & 12.87 \\
\hline $\begin{array}{l}\text { Management accounting and } \\
\text { control }\end{array}$ & 196.00 & $1,476.00$ & 1.16 & 8.66 & 7.48 & 4.14 & 4.09 \\
\hline Taxation & 41.00 & 324.00 & 0.27 & 2.08 & 7.74 & 0.87 & 0.90 \\
\hline Business and commercial law & 848.00 & $6,338.00$ & 5.22 & 39.03 & 7.47 & 17.93 & 17.55 \\
\hline Audit and assurance & 31.00 & 240.00 & 0.16 & 1.25 & 7.69 & 0.66 & 0.66 \\
\hline $\begin{array}{l}\text { Finance and financial } \\
\text { management }\end{array}$ & 242.00 & $1,727.00$ & 1.54 & 10.85 & 7.06 & 5.12 & 4.78 \\
\hline Financial markets & 143.00 & $1,092.00$ & 0.88 & 6.91 & 7.83 & 3.02 & 3.02 \\
\hline Economics & 662.00 & $5,269.00$ & 4.12 & 33.31 & 8.07 & 14.00 & 14.59 \\
\hline Business environment & 115.00 & 867.00 & 0.69 & 4.94 & 7.18 & 2.43 & 2.40 \\
\hline $\begin{array}{l}\text { International business and } \\
\text { globalisation }\end{array}$ & 94.00 & 767.00 & 0.46 & 3.88 & 8.39 & 1.99 & 2.12 \\
\hline Corporate governance & 50.00 & 349.00 & 0.27 & 1.67 & 6.23 & 1.06 & 0.97 \\
\hline Business ethics & 49.00 & 356.00 & 0.28 & 2.06 & 7.39 & 1.04 & 0.99 \\
\hline Organizational behavior & 135.00 & 974.00 & 0.77 & 5.62 & 7.25 & 2.85 & 2.70 \\
\hline $\begin{array}{l}\text { Management and strategic } \\
\text { decision-making }\end{array}$ & 517.00 & $3,989.00$ & 2.98 & 23.50 & 7.89 & 10.93 & 11.04 \\
\hline Marketing & 227.00 & $1,735.00$ & 1.24 & 9.53 & 7.69 & 4.80 & 4.80 \\
\hline General knowledge of IT & 115.00 & 460.00 & 0.80 & 3.08 & 3.87 & 2.43 & 1.27 \\
\hline IT control knowledge & 3.00 & 16.00 & 0.03 & 0.16 & 5.70 & 0.06 & 0.04 \\
\hline IT control competences & 1.00 & 10.00 & 0.01 & 0.06 & 10.00 & 0.02 & 0.03 \\
\hline IT user competences & 14.00 & 85.00 & 0.08 & 0.45 & 5.91 & 0.30 & 0.24 \\
\hline Designer of information systems & 13.00 & 81.00 & 0.07 & 0.46 & 6.18 & 0.26 & 0.22 \\
\hline Professional values and ethics & 40.00 & 157.00 & 0.15 & 0.62 & 4.25 & 0.85 & 0.43 \\
\hline Quantitative methods & 651.00 & $5,161.00$ & 4.31 & 32.22 & 7.47 & 13.76 & 14.29 \\
\hline Total value & $4,730.00$ & $36,121.00$ & 28.64 & 217.91 & 7.64 & 100.00 & 100.00 \\
\hline
\end{tabular}

Table E2

Knowledge Areas

\begin{tabular}{|c|c|c|c|c|c|c|c|}
\hline \multirow[b]{2}{*}{ Knowledge area } & \multicolumn{5}{|c|}{ Aggregate value } & \multicolumn{2}{|c|}{ Aggregate value (\%) } \\
\hline & $\begin{array}{l}\text { Total number } \\
\text { of subjects }\end{array}$ & Total MEC & $\begin{array}{l}\text { Mean number } \\
\text { of subjects }\end{array}$ & Mean MEC & $\begin{array}{l}\text { Mean MEC } \\
\text { per subject }\end{array}$ & $\begin{array}{l}\text { Total number } \\
\text { of subjects }\end{array}$ & Total MEC \\
\hline Business administration & $2,084.00$ & $16,230.00$ & 12.16 & 95.57 & 7.86 & 44.06 & 44.93 \\
\hline Economics & 912.00 & $7,227.00$ & 5.54 & 44.20 & 7.97 & 19.28 & 20.01 \\
\hline Business and law & 848.00 & $6,338.00$ & 5.22 & 39.03 & 7.47 & 17.93 & 17.55 \\
\hline Ethics & 89.00 & 513.00 & 0.43 & 2.69 & 6.31 & 1.88 & 1.41 \\
\hline IT & 146.00 & 652.00 & 0.98 & 4.20 & 4.29 & 3.09 & 1.81 \\
\hline Mathematics & 651.00 & $5,161.00$ & 4.31 & 32.22 & 7.47 & 13.76 & 14.29 \\
\hline Total value & $4,730.00$ & $36,121.00$ & 28.64 & 217.91 & 7.64 & 100.00 & 100.00 \\
\hline
\end{tabular}




\section{Appendix F}

Panel 6: Five-Year Degrees L33+L56

Table F1

Macro-subjects

\begin{tabular}{|c|c|c|c|c|c|c|c|}
\hline \multirow[b]{2}{*}{ Macro-subject } & \multicolumn{5}{|c|}{ Aggregate value } & \multicolumn{2}{|c|}{ Aggregate value (\%) } \\
\hline & $\begin{array}{l}\text { Total no. } \\
\text { of subjects }\end{array}$ & Total MEC & $\begin{array}{l}\text { Mean no. } \\
\text { of subjects }\end{array}$ & Mean MEC & $\begin{array}{l}\text { Mean MEC } \\
\text { per subject }\end{array}$ & $\begin{array}{l}\text { Total no. } \\
\text { of subjects }\end{array}$ & Total MEC \\
\hline $\begin{array}{l}\text { Financial accounting and } \\
\text { reporting }\end{array}$ & 146.00 & $1,270.00$ & 2.07 & 18.28 & 8.70 & 7.08 & 7.77 \\
\hline $\begin{array}{l}\text { Management accounting and } \\
\text { control }\end{array}$ & 22.00 & 151.00 & 0.27 & 1.97 & 6.86 & 1.07 & 0.92 \\
\hline Taxation & 47.00 & 372.00 & 0.66 & 5.19 & 7.91 & 2.28 & 2.28 \\
\hline Business and commercial law & 338.00 & $2,642.00$ & 4.55 & 35.69 & 7.82 & 16.38 & 16.16 \\
\hline Audit and assurance & 12.00 & 99.00 & 0.16 & 1.32 & 8.25 & 0.58 & 0.61 \\
\hline $\begin{array}{l}\text { Finance and financial } \\
\text { management }\end{array}$ & 43.00 & 330.00 & 0.51 & 3.95 & 7.67 & 2.08 & 2.02 \\
\hline Financial markets & 70.00 & 574.00 & 0.99 & 8.18 & 8.20 & 3.39 & 3.51 \\
\hline Economics & 575.00 & $4,705.00$ & 7.75 & 62.63 & 8.18 & 27.87 & 28.78 \\
\hline Business environment & 87.00 & 651.00 & 1.18 & 8.61 & 7.48 & 4.22 & 3.98 \\
\hline $\begin{array}{l}\text { International business and } \\
\text { globalisation }\end{array}$ & 51.00 & 413.00 & 0.68 & 5.44 & 8.10 & 2.47 & 2.53 \\
\hline Corporate governance & 2.00 & 17.00 & 0.02 & 0.17 & 8.50 & 0.10 & 0.10 \\
\hline Business ethics & 10.00 & 73.00 & 0.13 & 0.89 & 7.30 & 0.48 & 0.45 \\
\hline Organizational behavior & 17.00 & 122.00 & 0.26 & 1.91 & 7.18 & 0.82 & 0.75 \\
\hline $\begin{array}{l}\text { Management and strategic } \\
\text { decision-making }\end{array}$ & 108.00 & 840.00 & 1.44 & 11.29 & 7.78 & 5.24 & 5.14 \\
\hline Marketing & 20.00 & 162.00 & 0.20 & 1.73 & 8.10 & 0.97 & 0.99 \\
\hline General knowledge of IT & 56.00 & 219.00 & 0.84 & 3.56 & 3.91 & 2.71 & 1.34 \\
\hline IT control knowledge & 1.00 & 9.00 & 0.01 & 0.08 & 9.00 & 0.05 & 0.06 \\
\hline IT control competences & 0.00 & 0.00 & 0.00 & 0.00 & 0.00 & 0.00 & 0.00 \\
\hline IT user competences & 1.00 & 9.00 & 0.01 & 0.08 & 9.00 & 0.05 & 0.05 \\
\hline Designer of information systems & 10.00 & 72.00 & 0.10 & 0.75 & 7.20 & 0.49 & 0.43 \\
\hline Professional values and ethics & 3.00 & 17.00 & 0.06 & 0.20 & 5.67 & 0.15 & 0.10 \\
\hline Quantitative methods & 444.00 & $3,602.00$ & 6.16 & 49.49 & 8.11 & 21.52 & 22.03 \\
\hline Total value & $2,063.00$ & $16,349.00$ & 28.05 & 221.41 & 7.92 & 100.00 & 100.00 \\
\hline
\end{tabular}

Table F2

Knowledge Areas

\begin{tabular}{|c|c|c|c|c|c|c|c|}
\hline \multirow[b]{2}{*}{ Knowledge area } & \multicolumn{5}{|c|}{ Aggregate value } & \multicolumn{2}{|c|}{ Aggregate value (\%) } \\
\hline & $\begin{array}{l}\text { Total number } \\
\text { of subjects }\end{array}$ & Total MEC & $\begin{array}{l}\text { Mean number } \\
\text { of subjects }\end{array}$ & Mean MEC & $\begin{array}{l}\text { Mean MEC } \\
\text { per subject }\end{array}$ & $\begin{array}{l}\text { Total number } \\
\text { of subjects }\end{array}$ & Total MEC \\
\hline Business administration & 440.00 & $3,565.00$ & 5.93 & 48.80 & 8.10 & 21.33 & 21.81 \\
\hline Economics & 760.00 & $6,141.00$ & 10.27 & 81.87 & 8.08 & 36.84 & 37.56 \\
\hline Business and law & 338.00 & $2,642.00$ & 4.55 & 35.69 & 7.82 & 16.38 & 16.16 \\
\hline Ethics & 13.00 & 90.00 & 0.18 & 1.09 & 6.92 & 0.63 & 0.55 \\
\hline IT & 68.00 & 309.00 & 0.96 & 4.47 & 4.54 & 3.30 & 1.89 \\
\hline Mathematics & 444.00 & $3,602.00$ & 6.16 & 49.49 & 8.11 & 21.52 & 22.03 \\
\hline Total value & $2,063.00$ & $16,349.00$ & 28.05 & 221.41 & 7.92 & 100.00 & 100.00 \\
\hline
\end{tabular}

